Article

\title{
Negotiating Roles and Routines in Collaborative Investigative Journalism
}

\author{
Maria Konow-Lund \\ Department of Journalism and Media Studies, OsloMet, 0130 Oslo, Norway; E-Mail: mklu@oslomet.no
}

Submitted: 9 August 2019 | Accepted: 22 November 2019 | Published: 17 December 2019

\begin{abstract}
Over the past two decades, the practice of investigative journalism has been reconstructed via the rise of journalistic networks around the world that have layered collaboration atop what had long been an individual pursuit. Among the recent successes of collaborative investigative journalism was the cross-border effort to expose the tax haven leaks that included the Panama Papers (2016). Due to such notable accomplishments, research on cross-border collaboration is increasing, but the ways in which this pooling of resources, time, and networks has impacted practice on a daily basis remain underinvestigated. This article looks at how organizations and actors in emerging and legacy newsrooms are negotiating their routines and roles while developing new practices in investigative journalism. It uses three organizations as cases: Bristol Cable, a journalistic co-op operating at the community/local level; the Bureau Local, a local/national data-coordinating news desk; and The Guardian, a legacy media company that has long operated at the national/global level. This article finds that, in the transitions of traditional organizations and journalists and the emergence of new innovative organizations and non-journalistic actors, actors involved in collaborative investigative journalism deploy a language of justification regarding rules between the new and the old. It also finds that concepts such as coordination are part of this negotiation, and that knowledge and knowledge generation are taking place within a traditional understanding of journalism, as the "new" is normalized over time.
\end{abstract}

\section{Keywords}

collaboration; investigative journalism; journalistic roles; news ecology

\section{Issue}

This article is part of the issue "Peripheral Actors in Journalism: Agents of Change in Journalism Culture and Practice" edited by Avery E. Holton (University of Utah, USA), Valerie Belair-Gagnon (University of Minnesota-Twin Cities, USA), and Oscar Westlund (Oslo Metropolitan University, Norway / Volda University College, Norway / University of Gothenburg, Sweden).

(C) 2019 by the author; licensee Cogitatio (Lisbon, Portugal). This article is licensed under a Creative Commons Attribution 4.0 International License (CC BY).

\section{Introduction}

Studies on investigative journalism range from considering the origins of the practice in the muckraker period at the beginning of the twentieth century to mapping out aspects of the practice itself (Aucoin, 2005; Feldstein, 2006; Protess et al., 1991). Researchers have generally considered investigative journalism to be the most elevated type of reporting and the most esteemed role in the newsroom thanks to its aforementioned pedigree and crusader associations, which peaked with the exposure of the Watergate scandal in the 1970s (Schudson, 1992, pp. 115-116). Recently, academics have noted the retirement of the investigative journalist as a lone ranger in the context of a media ecology focused upon collaboration across borders (Berglez \& Gearing, 2018;
Carson \& Farhall, 2018). There remains a dearth of academic insight into this recent restructuring of investigative journalism (cf. Carson \& Farhall, 2018; Heft, Alfter, \& Pfetsch, 2017; Konieczna, 2018; Konow-Lund, Gearing, \& Berglez, 2019; Sambrook, 2018). In the aftermath of the Panama Papers story (2016), however, some academic and practitioner contributions to the field of research have emerged (Alfter, 2019; Graves \& Shabbir, 2019; Stonbely, 2017). There has also been interest in the digital technology behind journalistic collaboration (Baack, 2016, 2018). Yet, such studies can barely keep up with the field's ever-shifting disposition of a variety of actors and (often extensive) resources.

The present study looks at factors structuring this journalistic practice. Similarly to the recent study by Jenkins and Graves $(2019$, p. 7$)$, this article finds that 
"despite signs that collaboration can yield exponential benefits at the local level, these efforts have received less attention than high-profile national and international collaborations." It proceeds from a general definition of collaboration as sharing toward a common end (see Konow-Lund et al., 2019). Researchers have found it difficult to define investigative journalism, and some scholars insist that there is no single definition at all (Grøndahl Larsen, 2017). Tension exists concerning whether investigative journalism, as suggested by Stetka and Örnebring (2013), is like art, or whether it is a practice consisting of transferable skills. As James Aucoin (2005, p. 5). posits: "[It] progresses through the efforts of practitioners to meet and extend the practice's standards of excellence." Investigative journalism as a social practice evokes the work of the Investigative Reporters and Editors (IRE) in America (Baggi, 2011; Houston, 2009), which not only revitalized investigative journalism as a collaborative effort through its projects but also focused on computer-assisted reporting as initiated by Philip Meyer in the 1960s (Gynnild, 2013; Lewis, 2018). Offering bootcamps, training sessions, collaborative initiatives, and topic-driven projects, IRE came to define investigative journalism as "the reporting, through one's own initiative and work product, of matters of importance to readers, viewers or listeners. In many cases, the subjects of the reporting wish the matters under scrutiny to remain undisclosed" (Houston, 2009). Several scholars (Gearing, 2016; Konieczna, 2018) have also linked investigative journalism to public service journalism as the pillars of the fourth estate.

The three organizations chosen as cases focus on investigative journalism, they are in transitions somehow but more importantly represent cases which reach out to audiences in different but overlapping areas: Bristol Cable, is a journalistic co-op operating at the community/local level; the Bureau Local (BL), is a local/national data-coordinating news desk; and The Guardian, is a legacy media company that has long operated at the national/global level. In times of transformation and ongoing moves and adjustments between traditional organizations and innovative new organizations, and among seasoned professionals and actors with no prior experience in investigative journalism, the question becomes how the rules of practice can be negotiated, and in what language and with what terms.

\section{Routines and Roles in Organizational Context and Concrete Practices}

As journalism moves beyond traditional newsroom roles and practices (Ryfe, 2017) toward more untraditional forms of news production involving interprofessional roles such as hackers (Lewis \& Usher, 2014), app designers (Ananny \& Crawford, 2014), and suppliers of web analytics (Belair-Gagnon \& Holton, 2018), academics are sounding a familiar refrain: How can both scholar and practitioners capture and unpack change and innovation in emerg- ing and traditional news organizations? Ryfe (2011) notes that "researchers know very little about how some journalists are processing...changes" - that is, "about how the routines and practices of news production are changing [if at all], how journalists understand these changes, and what all of this means for the production of news or the self-conception of journalists" (2011, p. 165). Hence, the way in which routine is defined is central to any conversation about (or practice of) news production. Journalistic routines have been defined as "patterned, repeated practices and forms that media workers use to do their jobs" (Shoemaker \& Reese, 1996, p. 100). Ryfe (2017), however, does not think that routines actually guide practice but rather justify actions regardless of practice.

Ryfe (2017), as well as Westlund and Ekström (2019), prioritize a practical understanding of routine, as opposed to the industry-, habit-, or consensus-oriented definitions suggested by Shoemaker and Reese (1996). Ryfe (2017, p. 128) even turns to practice theory by suggesting that routines are "properly understood not as expressions of external pressures on journalists (whether understood as organizational, political, or economic pressures), but as cultural resources that bind journalists to a shared community of understanding." In doing so, Ryfe (2017) links news production to practical knowledge rather than formal knowledge. Routines may thus be connected to patterns of actions and understood "either as structured by organizational contexts, managed and reproduced in actions, or as shaped and worked out in social practices" (Westlund \& Ekström, 2019, p. 74). Westlund and Ekström's (2019) label suggests "that these dimensions refer to levels of social organization with distinct explanatory power." While the prior dimension refers to routines as characteristics of the organization preceding its stakeholders' concrete actions, the latter dimension refers to the way in which routines are the outcome of everyday practices and habitual and repetitive performances (Ryfe, 2017).

From an ethnographic point of view, it is important for fieldworkers to be able to detect when routines are planned and structured, or when they arise as a result of social activity. As Westlund and Ekström (2019, p. 74) point out, "routines both precede and are shaped within social activities." Westlund and Ekström (2019) use the two dimensions of organizational context and concrete practices to explore various aspects of the modernized and digitized production of news. One important aim of the organization is to generate knowledge, hence a need for routines. News actors must handle a lot of work in a systematic manner. Because the implementation of routines has always involved tacit knowledge (Tuchman, 1978), both organizations and actors must develop a language of justification for their routines and practices (Westlund \& Ekström, 2019, p. 81). The existence of knowledge construction in investigative journalism exposes inherent differences within this practice (Ettema \& Glasser, 1987), and "contexts of justification" indicate that epistemic claims in journalism are not ho- 
mogenous but rather depend upon a context (Westlund \& Ekström, 2019, p. 32). Practices in investigative journalism, including regular reporting or contacting sources, come with what Ettema and Glasser $(1987$, p. 344) call "pre-justified facts."

Ultimately, two aspects define the approach of this news ethnography: (1) to understand ongoing change, it is important to closely engage with how routines are invoked and negotiated; and (2) this needs to approach in a synthesis organizational context and concrete practices, where knowledge construction and knowledge coordination are vital resources in this endeavor.

\section{Method and Empirical Material}

This article draws upon three case studies involving semistructured qualitative interviews with twenty news workers from three different organizations. These three cases all have alternative working models for investigative journalism. They also all focus on how to link the local with the national. And they all require workers to adjust to new roles and skills. Some scholars state that case studies are useful when the researcher is asking "how" and "why" questions; when the researcher has little control over what happens; and when the focus is on "holistic and meaningful characteristics of real-life events" (Yin, 2003, p. 2) -in this case, the impact of collaborative practice and changes in digital technology upon journalistic routines and roles at both new and established news organizations. Two of the cases are innovative start-ups focused on interacting with citizens and involving communities (i.e., Bristol Cable and BL). The third case is a legacy organization, The Guardian. Journalistic roles at these places include traditional and hybrid functions involving reporting, coordination, and community engagement, as well as more peripheral actors such as citizens, activists, and hackers. The article's analytical approach involves a hermeneutic analytical process often used in traditional news ethnographies (Gans, 1979/2004; Schlesinger, 1978; Tuchman, 1978) that generates data not only through field observations, field interviews, and semi-structured qualitative interviews but also through internal documents and, importantly, repeated observation stints at different times. For example, I revisited both Bristol Cable and the BL some months after my initial visits, and I followed up with various The Guardian informants long after my single visit there for semi-structured qualitative interviews conducted outside the newsroom. Knut Helland (1993, p. 95) argues that "fieldwork may be seen as a special kind of hermeneutic activity: different situations and processes are conceived differently during varying stages of the research project through conceptual refinements" (see also Johansen, 1981; Wadel, 1991). That is, the combination of field observation and semi-structured qualitative interviews enables the ongoing elaboration of one's analyses by soliciting objections, clarifications of assumptions and conclusions, and more specific questions.
My research methodology included three weeks of field observation at Bristol Cable, four weeks of field observation (spread over a period of about seven months) at the $\mathrm{BL} / \mathrm{Bureau}$ for Investigative Journalism (BIJ), and three days of field observation at The Guardian, all combined with twenty semi-structured qualitative interviews with anonymized stakeholders. Bristol Cable is a nonprofit co-op with two thousand paying members as of July 2019. It generates both workshops and events such as annual meetings for members and open meetings for the general public, and it produces a quarterly newspaper. It has gained funding from various mediaand journalist-supporting organizations, including the Omidiyar Network. BL is a Google and philanthropically funded platform that is part of the BIJ, which supports BL when necessary. The print newspaper The Guardian was founded in 1821, and in 2011 it rolled out a "digital first" strategy that led to a significant increase in readers globally. Despite recent financial losses, The Guardian remains known for its quality journalism, including exposés such as the Panama Papers, the Paradise Papers, Cambridge Analytical, and the Facebook scandal. The Guardian has traditionally been funded by the Scott Trust (1936), which was established to secure its editorial independence, and it is a traditional representative of the liberal British press (Ilan, 2012, p. 39). I selected these case studies in order to compare new entrepreneurial organizations (Bristol Cable, the $\mathrm{BL}$ ) to a legacy organization with recent experience in adapting to the digital era (The Guardian). The following sections first explain the structure of the organization in question, then engage with any change to its routines or roles.

\section{Roles at the Co-Op: From Criticizing Journalism to Becoming Journalists}

The co-op Bristol Cable arose when three college friends wanted to fill a gap in the British local media market (Informant, 22 December 2017; Informant, 26 January 2018 ) in terms of holding power to account. Their local media was suffering in the recession, and publications were shutting down, so the Bristol Cable founders conceived of an organization that could generate collaborations with citizens and engage the local community. In short, they framed their journalism as a tool for effecting change in their "immediate surroundings" (Informant, 22 December 2017). The goal of Bristol Cable was to demonstrate that holding power to account does not require a hierarchical journalistic organizational structure; instead, shared values and goals alone might sustain an organization that could accommodate the input of the people themselves in the work to be done. Bristol Cable produced a quarterly newspaper and generated events where members were invited to learn about the media industry and make decisions about stories and coverage through a flat structure for production. In keeping with this approach, everyone who was involved in the organization received the same compensation, which at 
the beginning was the minimum wage. One informant lamented: "I'm not earning enough money to live off of the Cable. It costs me to work for the Cable, in some ways, not even thinking about lost potential earnings" (Informant, 21 December 2017). This informant circled back to this comment in 2019:

We're now paid enough to get by, though the salary is far from competitive, and love of the mission and work is the main motivator. But getting paid has been vital both for valuing our work and for allowing us to give time to the Cable rather than needing to work another job or draw on savings. As we grow older, with years of experience behind us and some anticipating having children, we will need to further increase our salaries to remain sustainable or lose the staff who can't afford to stay on a minimum wage. (Informant, 7 August 2019)

Early on, in fact, everyone had to find additional ways to support themselves-two of the founders worked in the catering business, and other staff members lived on their savings (Informant, 21 December 2018). Position titles were deliberately chosen to avoid hierarchical implications, though the journalistic work had certain inherent demands for a structure (Tuchman, 1978), meaning that even when everyone in the room was called a media coordinator, they were doing different things.

My fieldwork at Bristol Cable uncovered other fractures in the ideal of the flat organizational structure, as a positional hierarchy had begun to emerge simply to enable the allocation of tasks to avoid redundancy and maximize efficiency. My informants were at this time claiming to actively seek to restructure the co-op based on this evolution, using daylong meetings to work toward a shared set of values, norms, and practices to inform the organization. The meetings were meant to coordinate communication and articulate shared goals in order to develop routines, practices, and roles that mitigated potential tension and conflict. During these meetings, there was always a demonstration of mutual respect, but there were also honest discussions about how to remain "horizontal" while actually doing the work. One informant pointed to the need to juggle a variety of roles, which was both challenging and constructive:

I'm a sub-editor and a co-editor and a commissioning editor and a journalist and a sort of production manager, like, just having all the different things....It's very challenging. I wish I had more time to do bigger pieces of journalism, but it makes for an interesting job. If I were in mainstream media as a journalist, I wouldn't have the choice about what I went and covered and investigated and stuff, so that's a massive plus. Having the freedom to choose what you do and how you do it is really different. And not just being told what to do, having a say in what we do, and how, is totally different from any mainstream media. (Informant, 26 January 2018)
Various interviews with Bristol Cable actors, as well as my observations during fieldwork (2017), revealed contradictions and tensions when it came to who should do what at the co-op. One reason for this might be that most informants at Bristol Cable had started there with little journalistic experience. The informant above refers disparagingly to mainstream journalism, but, in fact, knows very little about it. When I asked about this contradiction while conducting my fieldwork, my informants explained that they were learning by doing, and some of them were picking up ideas and suggestions at journalism conferences or from local professional journalists with whom they were collaborating (field observation, 9 November 2017). The perceived hope at Bristol Cable, as mentioned above, was to create a viable journalistic organization through which citizens could hold local power to account, and the process was every bit as important as the product, my informants emphasized. A horizontal newsroom structure, in turn, meant that ideas and topics could come from citizens as well as founders or reporters or colleagues elsewhere. One Bristol Cable initiative turned into a collaboration with the BIJ/BL and The Guardian to address the fact that one in five people stopped by immigration enforcement teams in Britain was a UK citizen. In this collaboration, the coordination stayed with Bristol Cable, while BIJ/BL added technological expertise and professionalism; together, they were able to access Home Office data on this situation. One BIJ/BL informant applauded the fact that Bristol Cable sought to deploy a cross-institutional collaboration to extend the impact of the story beyond the local, perhaps lending it national political resonance (and even resolution; informant BIJ/BL, 15 December 2017). This story was published in The Guardian (Gayle, Boutaud, \& Cantwell-Corn, 2017) but also on a number of local news outlets.

As Bristol Cable followed through on its idealistic organizational project, stakeholders encountered several challenges. One challenge was reconciling their personal ideals to the necessity of producing quality watchdog journalism that was the product of professionalized collaborations with The Guardian or the BL. Another was spreading the concept of a citizens' media co-op by developing a media hub for live events, holding open meetings, and knocking on doors. There was also the need to enter into professional arrangements to prompt engagement from local journalists. When I observed discussions at Bristol Cable about how to adjust norms and values, people kept mentioning participation, transparency, and holding power to account. As one informant said at a meeting, "We aim to have an organization where citizens can create their own media" (field observation, Bristol Cable, 10 November 2017). Another informant mentioned that they needed to balance the ideal of participation with the aim of creating a product that the reader would enjoy reading (lbid). The most important value involved the ability to challenge injustice in society, and the importance of having an impact was emphasized several times (field observation, Bristol Cable, 
10 November 2017). It was pointed out that the media organization should be "locally focused but globally and nationally minded" (field observation, Bristol Cable, 10 November 2017).

These discussions made it clear that informants had observed an increase in mutual support and solidarity among journalist organizations, or what was frequently referred to as a "collaborative atmosphere," and that it was motivating the staff at Bristol Cable to work hard to inspire its members to participate. Ultimately, though they started out by being highly critical of the legacy media in general, several informants noted that they had come to respect the work of investigative journalists, and that watchdog journalism was useful at Bristol Cable in terms of its impact. As these amateurs had become professionals, they developed the discernment to make productive choices and explain them to others.

\section{The BL: Roles for Connecting People and Preparing Impact Journalism}

While Bristol Cable stakeholders had little experience with professional journalism, the BL involved actors with journalistic backgrounds, including education and/or experience, from the start. The BL was the brainchild of the managing editor of the BIJ, who had tracked International Consortium of Investigative Journalists as it managed and coordinated the Panama Papers-related work of nearly 400 journalists from 80 different countries and 107 different media outlets. This editor wondered whether this type of international collaboration, organized around a more proactive data hub, could succeed on the national level as well. Located within the BIJ, an independent nonprofit established in 2010, the BL was surrounded by traditional investigative journalists and their practices. The idea behind the BL was to address what Howells (2015, pp. 1-2) calls journalistic "black holes" following the demise of so many local media organizations in a hypercompetitive and digitally driven national media market.

Proactivity characterized the ways in which news were made and the news desk was structured at the $\mathrm{BL}$. Journalists would arrange events to engage the public in discussions about holding power to account, then establish collaborations in an interdisciplinary manner. My fieldwork took place in 2017 and the spring of 2018, the year in which the platform was established, so it reflects the earliest days at this organization. From the start, the BL focused on building bridges between its stakeholders and local journalists, as well as activists, bloggers, hackers, and journalism students around the country, sharing data and stories via the software platform Slack, a digital collaboration tool to which recent studies attribute "enormous potential" (Bunce, Wright, \& Scott, 2018) for establishing and accommodating productive relations across great geographical distances. In the present context, though, the flipside of such virtual newsrooms is the difficulty actors have in distinguish- ing between the private and professional spheres (Bunce et al., 2018).

At the $\mathrm{BL}$, Slack is just one of many tools used to bridge actors in the local mediascape. Both the director of the $\mathrm{BL}$ and the managing editor at the BIJ emphasized a combination of physical media events and an effort to render data journalism as accessible as possible. The BL director emphasized how they worked hard "to talk to people about the idea, to get people to sign up for it, and we took a lot of notes about that. We met with freelancers, we met with local newsrooms, we met with just loads of people" (interview, 26 April 2018). The first real test for the $B L$ came right away, in fact, when then Prime Minister Teresa May suddenly announced an election. Instead of slowly coming together as a new organization, the BL had to jump right in and produce journalism immediately. The urgency, in a sense, came to define the team (and the organization) as it chose tools and instigated collaborations.

While $B L$ aimed to engage a variety of actors within the new media ecology, its larger goal was to create an environment for collaboration. Some informants pointed out that the Panama Papers investigation was not really a collaborative effort but a cooperative one, whereby exclusive content was shared among individuals as well as organizations (Konow-Lund et al., 2019). BL, on the other hand, was about collaboration in a very creative sense:

Collaborative is when we had that spreadsheet on immigration where all the local reporters who were working on the investigation were inputting all the great quotes from the interviews they did. So, there was the name of the reporter, the people they interviewed, what's the job of the people interviewed, is it a member of Parliament, is it a lawyer, is it a community organizer, is it a person from a campaign organization, an academic? And then these are the questions I asked, and these were the answers. (Informant, 15 December 2017)

Because my observation took place just as BL started up, my informants described its members as primarily local journalists. The organization's ideal was a high standard of journalistic practice and product through interdisciplinary collaboration among different actors, all of whom stood to benefit from the professional assistance of the BL:

The core work in Bureau Local is done by our team, who are all professional journalists, and many of the journalists they work with are professional, longstanding local reporters. In each story investigation that they have done, there have been a couple of people who are not what you would call traditional journalists, but they benefit from the information, from our data, from our reporting recipes, from support that is available at Bureau Local. (Managing Editor, BIJ, 18 April 2018) 
Cross-institutional collaboration is one of several structural changes enabling local and national watchdog journalism. What some interviewees called the "new news ecology" of investigative journalism involves not only reaching a versatile audience with one's journalistic products but also engaging a variety of interprofessional actors in the creation of those products. Both Bristol Cable and the BL have taken giant steps in this regard, and onceperipheral roles have become normalized in the process, either from within the organization or from outside demand (such changes are also behind the development of data journalist positions at The Guardian, which was confronted by the same new news ecology as Bristol Cable and the $\mathrm{BL}$ ).

Some informants admitted that they were careful not to take on any editorial responsibility for the stories produced by their network collaborators:

That's the kind of interesting thing about the model, the ownership and responsibility element, because we don't own the stories that those local people are putting out and, in a way, we can't be responsible for everyone....I think it should be [the case] that those people are responsible in their own way for what they do, and that they're aware of the consequences of getting it wrong. If we make a mistake and we give them bad information, then absolutely that's our fault. (Informant, 15 December 2017)

This editorial responsibility extends to whomever the Slack correspondent or BL member might be, as well, because any blogger, influencer, local journalist, activist, community figure, or engaged citizen can log into the $\mathrm{BL}$ and become a member. At the time of my fieldwork, there were five people at the BL: the director, two journalists, a onetime data editor at The Sunday Times, and a data journalist. Soon afterward, another person was hired as a community organizer. This team functioned both as a group of coordinators and as an editorial newsroom to do its own research for certain stories. One informant noted that if collaborators from the BL media ecology called and asked for help, they would receive advice and instructions (Informant, 15 December 2017). Early on in my fieldwork (and in the history of Bristol Cable), the director presented a strategy for analyzing norms and values with her staff, approaching issues in a bottomup manner. Although she was always open to input, it was clear that she would make the ultimate decisions. In other words, while Bristol Cable aimed for a horizontal newsroom across the organization, it relied on a hierarchy that was more typical of a traditional newsroom.

\section{The Guardian: Serving the Newsroom and Adding Exclusivity and Impact}

Developing relationships between newer roles and legacy roles occupied some of my interviews at The Guardian, a legacy media platform that was established in 1821 and has a deeply rooted traditional culture and production history. The Guardian distinguishes itself from the other cases by its legacy status. In interviews, that is, senior investigative journalists at The Guardian can draw upon firsthand experience to decide whether Julian Assange was a hacker or a proper editor-in-chief of a news outlet (Senior Reporter, 26 July 2018; Senior Reporter/Editor, 26 April 2018). They decided he was a hacker who lacked the skillset of an investigative journalist, including a certain attitude toward watchdog reporting, a certain mindset, an aversion to personal fame, and a level of technical facility. Their experience with WikiLeaks helped them to better distinguish between professional collaboration and other kinds, such as collaborations with activists who are better considered sources than partners (Senior Reporter, 26 July 2018). This reporter also noted that cross-border collaboration thrives when journalists share access to otherwise exclusive or unfamiliar sources.

Current newsroom roles at The Guardian derive from the ways in which the organization has had to adapt to accelerated technological developments, and there was a tension between traditional reporters and those more digital-savvy actors (designers, coders, visual designers, data journalists, and so on), especially regarding bylines and acknowledgment of work. One young digital reporter believes it boils down to control of the work process:

The people who have been here for a long time are not happy to give up a lot of their control. So both when it comes to just having a name on something and when it comes to internal structures, obviously a lot of people would prefer it if they are kept in the driving seat and they can ask us for our help with something when they think they need it. (Interview, Digital Reporter, 7 September 2018)

During large investigations such as the Panama Papers, a number of newsroom workers, including graphic designers and the visuals team, are involved. According to one informant (27 July 2018), there had been a shift from a focus on how roles contribute individually to how they can all work together across the newsroom. Various informants emphasized the importance of being able to come up with breaking news stories and offer exclusive news stories even through data journalism or digital tools. Excel was mentioned as a particularly useful way to find, source, and strengthen stories and analyze data (Interview, Digital Reporter, 6 August 2018).

Some informants also emphasized the challenges of distinguishing oneself in the newsroom, given the ongoing collision of traditional and new practices; one journalist described the media landscape as "difficult" and noted that there was little to no money when one first started out (Informant, 27 July 2018). This informant also found that it became important to shape a role for herself by doing things other journalists would not do 
or by developing extra skills that senior journalists did not have, such as an improved competency with spreadsheets. She concluded that while having data skills is important, a successful journalist still needs to tell a good story above all else. The former was easy to teach; the latter, less so. This aspect of success-developing a specialty so as to stand out as a news worker-was stressed by several informants in The Guardian newsroom and echoed a view held by staff at the BL and the Bristol Cable as well.

Other informants who worked with data also emphasized that exclusive stories nowadays arose from effective approaches to digital technology, in addition to legwork and traditional skills. To do this work well, data journalists had to collaborate with others in the newsroom and come up with their own ideas as well. The balance between serving the newsroom and distinguishing oneself as a proper journalist came up in several interviews:

We're not a service desk, we are journalists. We're journalists by training and experience, and when you're a journalist and you get that thirst for finding and publishing, getting your own stories, I don't think it ever leaves you. The thing is, our journalism works in several different ways. People often ask, so are you commissioned by the desk or do you come up with your own stuff? And it's a mixture of everything. People will say, where do you come up with your story ideas, and you say, it's just everywhere, like, any conversation you have, any newspaper article you read, anything you hear potentially has the seed of a story idea. My sister says that on my gravestone I should have "there could be a story in this," which I really like the idea of. (Informant, 6 August 2018)

One informant (7 September 2018) specializing in digital technology revealed great insight into his role at The Guardian in terms of the importance of a byline. To him, a byline was evidence of his contribution, both internally and externally, and it specifically recognized the fact that data and visuals had made the story great in the first place (informant, 7 September 2018). He hoped that emerging roles such as his would be normalized and professionalized over time, despite the persistence of "traditional thinking" when it comes to what he does.

\section{Discussion and Conclusion}

To fill a gap in research that "makes direct observation of journalistic practice and how it is produced and reproduced in performance" (Westlund \& Ekström, 2019, p. 84), this study has engaged three types of organizations dedicated to public affairs journalism with a collaborative bent. While other recent studies have focused on how interprofessional actors collaborate in and with today's newsrooms, this study looked at how routines and practices arise both within as well as between organizations dedicated to emerging collaborative investigative news production. This new news ecology is characterized by the participation of actors with little or no prior experience in journalism alongside professional actors and their established practices and routines. Because routines justify actions (Ryfe, 2017), new actors and organizations must develop a language for justifying routines and practices, which are no longer taken for granted in the cultural context of a shared community. This study found that negotiations about this narrative take place internally but also externally, at events, conferences, and seminars and hence influence the collaborative actors in various ways.

While the recent rise in cross-border collaborations has received a lot of attention from journalist scholars (Berglez \& Gearing, 2018; Carson \& Farhall, 2018; KonowLund et al., 2019), the collaborative potential of journalistic practice at the local, national and global levels is yet to be addressed. At the same time, as demonstrated by the emergence of studies on how a journalistic process attracts a variety of both traditional as well as peripheral actors, the question is how such a variety of actors would engage in routines understood as "cultural resources that bind journalists to a shared community of understanding" (Ryfe, 2017, p. 128). This study concludes by stressing the importance of improving and advancing understanding and research concerning: (1) how to position cultural resources such as routines between both traditional and emerging actors; (2) how to interpret such cultural resources as routines in the midst of both traditional and new practices; and (3) how to coordinate the knowledge generated between the old and the new (Westlund \& Ekström, 2019).

Ultimately, this study shows that the variety of actors and emerging stakeholders in investigative journalism are aligned (or not aligned) in terms of the field's shared norms, values, and taken-for-granted rules. Ryfe (2017) argues that rules serve as the justification for certain actions over others. The present study responds to the critique raised by Westlund and Ekström (2019, p. 85) that "ethnographic newsroom research has been close to concrete practices but has most often focused on the routines as such rather than how they are invoked and negotiated." By devoting an ethnographic study to an organization with non-journalists, another with both nonjournalists and professionals, and finally one with very professional journalists, this study emphasize how routines as cultural resources are being renegotiated more than coordinated.

Bristol Cable, for example, which had no prior experience with journalistic practice, had to justify why their particular routines and practices constituted journalism at all (see Ryfe, 2017). This process generated a sophisticated narrative developed through long discussions about their values and norms among all stakeholders, including owners, staff, and members. Although the $\mathrm{BL}$ and The Guardian required fewer words to justify their routines and practices, given their longer-standing claims to the profession, they also needed to make their 
work and their thinking explicit when newcomers to their newsroom or inter-organizational collaborative ecology would arrive. These different actors then would contribute different narratives to the field. Over time, all three organizations saw their new narratives and professional roles normalized within the larger journalistic organizational and occupational discourse.

The three organizations under scrutiny in this study were tacitly aware of the fact that anything that could function as a neutral intermediary would help to coordinate the new ecology's routines, practices, and roles. Such an intermediary could be a position title such as Bristol Cable's "coordinators," the collaborative software at $\mathrm{BL}$, or The Guardian's shared and expressed set of values and professional ideas. "Coordination," then, enables actors to collaborate; it can also become a vehicle for the unspoken convergence of traditional professional identities, to the detriment of those actors and the organizations they represent. It is not always clear whether such neutral intermediaries represent a means of accomplishing a shared aim or a tacit strategy for coping with ongoing differences and tensions in the workplace. The implementation of routines and practices brings about tension, after all. Future research could look at why some actors or organizations do better than others in these negotiations, and whether entities prefer to adapt to the new or settle for existing rules and practices.

To summarize, this study reveals how the negotiations both within and between new and legacy actors can shed light upon how routines and practices change in response to a new ecosystem, as well as how these changes are implemented both online and offline. More research is required to build out our understanding of what takes place when traditional rules and practices come up against new roles and priorities.

\section{Acknowledgments}

This project received funding from the European Union's Horizon 2020 research and innovation program under the Marie Skłodowska-Curie grant agreement No. 746899. The project was located at the School of Journalism, Media and Culture, Cardiff University, CF 10 1FS, Cardiff, UK, between 2017 and 2019. Thanks to my supervisor, Professor Karin Wahl-Jorgensen, and to Professors Simon Cottle and Richard Sambrook at Cardiff University for their advice and comments on the Marie Skłodowska-Curie project. A special thanks to the anonymous reviewers and for the particularly useful guidance of editors Avery Holton, Valerie Belair-Gagnon, and Oscar Westlund.

\section{Conflict of Interests}

The author declares no conflict of interests.

\section{References}

Alfter, B. (2019). Cross-border collaborative journalism: A step-by-step guide. London: Routledge.

Ananny, M., \& Crawford, K. (2014). A liminal press: Situating news app designers within a field of networked news production. Digital Journalism, 3(2), 192-208.

Aucoin, J. (2005). The evolution of American investigative journalism. Columbia, MO: University of Missouri Press.

Baack, S. (2016). What big data leaks tell us about the future of journalism-and its past. Internet Policy Review. Retrieved from https://policyreview.info/ articles/news/what-big-data-leaks-tell-us-aboutfuture-journalism-and-its-past/413

Baack, S. (2018). Practically engaged. Digital Journalism, 6(6), 673-692. https://doi.org/10.1080/21670811. 2017.1375382

Baggi, G. (2011). Nonprofit investigative journalism in Europe: Motives, organisations and practices (Unpublished Masters dissertation). University of Hamburg, Hamburg, Germany.

Belair-Gagnon, V., \& Holton, A. E. (2018). Boundary work, interloper media, and analytics in newsrooms. Digital Journalism, 6(4), 492-508.

Berglez, P., \& Gearing, A. (2018). The Panama and Paradise papers: The rise of a global fourth estate. International Journal of Communication, 12, 4573-4592.

Bunce, M., Wright, K., \& Scott, M. (2018). "Our newsroom in the cloud": Slack, virtual newsrooms and journalistic practice. New Media and Society, 20(9), 3381-3399.

Carson, A., \& Farhall, K. (2018). Understanding collaborative investigative journalism in a "post-truth" age. Journalism Studies, 19(13), 1899-1911.

Ettema, J., \& Glasser, T. (1987). On the epistemology of investigative journalism. In M. Gurevitch \& M. R. Levy (Eds.), Mass communication yearbook. London: Sage.

Feldstein, M. (2006). A muckraking model: Investigative reporting cycles in American history. International Journal of Press/Politics, 11(2), 105-120.

Gans, H. J. (2004). Deciding what's news: A study of CBS Evening News, NBC Nightly News, Newsweek, and Time. Evanston, IL: Medill School of Journalism, in association with Northwestern University Press. (Original work published 1979)

Gayle, D., Boutaud, C., \& Cantwell-Corn, A. (2017, October 8). One in five stopped by immigration enforcement is a UK citizen, figures show. The Guardian. Retrieved from https://www.theguardian.com/uknews/2017/oct/08/one-in-five-stopped-byimmigration-enforcement-is-a-uk-citizen-figuresshow

Gearing, A. (2016). Global investigative journalism in the network society (Unpublished Doctoral dissertation). Queensland University of Technology, Queensland, Australia. 
Graves, L., \& Shabbir, N. (2019). Gauging the global impacts of the "Panama Papers" three years later. Oxford: The Reuters Institute for the Study of Journalism.

Grøndahl Larsen, A. (2017). Investigative reporting in the networked media environment. Journalism Practice, 11(10), 1231-1245. https://doi.org/10.1080/ 17512786.2016.1262214

Gynnild, A. (2013). Journalism innovation leads to innovation journalism: The impact of computational exploration on changing mindset. Journalism, 15(6), 713-730.

Heft, A., Alfter, B., \& Pfetsch, B. (2017). Transnational journalism networks as drivers of Europeanisation. Journalism, 18(5), 1183-1202.

Helland, K. (1993). Public service and commercial news: Contexts of production, genre conventions and textual claims in television (Report 18). Bergen: University of Bergen.

Houston, B. (2009). The investigative reporter's handbook: A guide to documents, databases and techniques (5th ed.). Champaign, IL, and Boston, MA: University of Illinois at Urbana-Champaign and Bedford/St. Martin's.

Howells, R. (2015). Journey to the centre of a news black hole: Examining the democratic deficit in a town with no newspaper (Unpublished Doctoral dissertation). Cardiff University, Cardiff, Wales, United Kingdom.

Ilan, J. (2012). Picturing the world's news: News photography, cultural production, Thomas Reuters and the international process of news making (Unpublished Doctoral dissertation). Westminster University, London, United Kingdom.

Jenkins, J., \& Graves, L. (2019). Case studies in collaborative local journalism. Oxford: Reuters Institute for the Study of Journalism. Retrieved from https:// reutersinstitute.politics.ox.ac.uk/our-research/casestudies-collaborative-local-journalism

Johansen, A. (1981). Feltarbeid i sosialantropologien: fra observasjoner til data [Fieldwork in anthropology: From observation to data]. Antropolognytt, 3(2), 5-27.

Konieczna, M. (2018). Journalism without profit: Making news when the market fails. New York, NY: Oxford University Press.

Konow-Lund, M., Gearing, A., \& Berglez, P. (2019). Transnational cooperation in journalism. Oxford Research Encyclopedias. Retrieved from https:// oxfordre.com/communication/view/10.1093/ acrefore/9780190228613.001.0001/acrefore- 9780190228613-e-881

Lewis, C. (2018). Tear down these walls: Innovations in collaborative accountability research and reporting. In R. Sambrook (Ed.), Global teamwork: The rise of collaboration in investigative journalism (pp. 5-25). Oxford: Reuters Institute for the Study of Journalism.

Lewis, S. C., \& Usher, N. (2014). Code, collaboration, and the future of journalism. Digital Journalism, 2(3), 383-393.

Protess, D. L., Cook, F. L., Doppelt, J. C., Ettema, J. S., Gordon, M. T., \& Leff, D. L. (1991). The journalism of outrage: Investigative reporting and agenda building in America. New York, NY: Guilford Press.

Ryfe, D. (2011). Broader and deeper: A study of newsroom culture in a time of change. In D. A. Berkowitz (Ed.), Cultural meanings of news: A text reader (pp. 165-177). Los Angeles, CA: Sage.

Ryfe, D. (2017). News routines, role performance, and change in journalism. In C. Mellado, L. Hellmueller, \& W. Donsbach (Eds.), Journalistic role performance: Concepts, contexts, and methods. London: Routledge.

Sambrook, R. (2018). Global teamwork: The rise of collaboration in investigative journalism. Oxford: Reuters Institute for the Study of Journalism.

Schlesinger, P. (1978). Putting "reality" together: BBC News. London: Methuen.

Schudson, M. (1992). Watergate in American memory: How we remember, forget, and reconstruct the past. New York, NY: Basic Books.

Shoemaker, P. J., \& Reese, S. (1996). Mediating the message: Theories of influences on mass media content. White Plains, NY: Longman.

Stetka, V., \& Örnebring, H. (2013). Investigative journalism in central and eastern Europe: Autonomy, business models, and democratic roles. International Journal of Press/Politics, 18(4), 413-435.

Stonbely, S. (2017). Comparing models of collaborative journalism. Montclair, NJ: Center of Cooperative Media, Montclair State University.

Tuchman, G. (1978). Making news: A study in the construction of reality. New York, NY: Free Press.

Wadel, C. (1991). Feltarbeid I egen kultur [Fieldwork in own culture]. Flekkefjord: SEEK.

Westlund, O., \& Ekström, M. (2019). News organizations and routines. In K. Wahl-Jorgensen \& T. Hanitzsch (Eds.), The handbook of journalism studies (2nd ed.; pp. 73-89). New York, NY: Routledge.

Yin, R. K. (2003). Case study research: Design and methods (3rd ed.). Thousand Oaks, CA: Sage.

\section{About the Author}

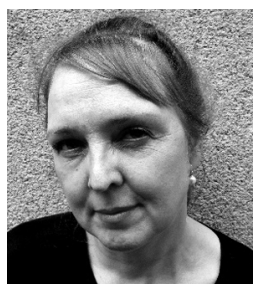

Maria Konow-Lund (PhD), Associate Professor at the Department of Journalism and Media Studies, Oslo Metropolitan University, and EU-funded Skłodowska-Curie fellow, Cardiff University (2017-2019), focuses on how investigative journalism is being restructured due to emerging organizations and a changing media ecology. She has published in Digital Journalism, Journalism Practice, Nordicom Review, and in the Routledge Companion to Media and Humanitarian Action (2017). She also has many years of experience as a professional journalist at Norwegian Broadcasting and elsewhere. 